\title{
The European sea bass Dicentrarchus labrax genome puzzle: comparative BAC-mapping and low coverage shotgun sequencing
}

\author{
Heiner Kuhl ${ }^{*}$, Alfred Beck', Grzegorz Wozniak', Adelino VM Canario ${ }^{2}$, Filip AM Volckaert ${ }^{3}$, Richard Reinhardt ${ }^{1}$
}

\begin{abstract}
Background: Food supply from the ocean is constrained by the shortage of domesticated and selected fish. Development of genomic models of economically important fishes should assist with the removal of this bottleneck. European sea bass Dicentrarchus labrax L. (Moronidae, Perciformes, Teleostei) is one of the most important fishes in European marine aquaculture; growing genomic resources put it on its way to serve as an economic model.

Results: End sequencing of a sea bass genomic BAC-library enabled the comparative mapping of the sea bass genome using the three-spined stickleback Gasterosteus aculeatus genome as a reference. BAC-end sequences $(102,690)$ were aligned to the stickleback genome. The number of mappable BACs was improved using a two-fold coverage WGS dataset of sea bass resulting in a comparative BAC-map covering $87 \%$ of stickleback chromosomes with 588 BAC-contigs. The minimum size of 83 contigs covering 50\% of the reference was $1.2 \mathrm{Mbp}$; the largest BAC-contig comprised $8.86 \mathrm{Mbp}$. More than 22,000 BAC-clones aligned with both ends to the reference genome. Intra-chromosomal rearrangements between sea bass and stickleback were identified. Size distributions of mapped BACs were used to calculate that the genome of sea bass may be only 1.3 fold larger than the $460 \mathrm{Mbp}$ stickleback genome.

Conclusions: The BAC map is used for sequencing single BACs or BAC-pools covering defined genomic entities by second generation sequencing technologies. Together with the WGS dataset it initiates a sea bass genome sequencing project. This will allow the quantification of polymorphisms through resequencing, which is important for selecting highly performing domesticated fish.
\end{abstract}

\section{Background}

Teleost fishes are the most diverse group of vertebrates, with approximately 28,000 species, which have colonized a range of aquatic environments and display a variety of biochemical, physiological and morphological adaptations $[1,2]$. Because of this diversity and their position at the base of the vertebrate phylogeny, some species are considered good models of evolution, development and human diseases [3-6]. For this reason, teleost species were among the first vertebrate genomes to be sequenced: the green spotted pufferfish, Tetraodon nigroviridis [7] and the fugu Takifugu rubripes [8] for their relatively small compact genome; the medaka

\footnotetext{
* Correspondence: kuhl@molgen.mpg.de
${ }^{1}$ Max Planck Institute for Molecular Genetics, Ihnestr. 63, D-14195 Berlin,

* Correspondence: kuhl@molgen.mpg.de
${ }^{1}$ Max Planck Institute for Molecular Genetics, Ihnestr. 63, D-14195 Berlin, Germany
}

(c) 2010 Kuhl et al; licensee BioMed Central Ltd. This is an Open Access article distributed under the terms of the Creative Commons Attribution License (http://creativecommons.org/licenses/by/2.0), which permits unrestricted use, distribution, and reproduction in any medium, provided the original work is properly cited.
Oryzias latipes [9] and the zebrafish Danio rerio [10] for ease of maintenance and amenity to genetic manipulations [11,12]; and the three-spined stickleback, Gasterosteus aculeatus http://www.ensembl.org as a model for evolution [13]. However, no representative of the Perciformes, the most advanced and diverse group of teleosts has been sequenced and genomic resources for this taxonomic group are relatively limited. Furthermore, no aquaculture fish species has had its genome sequenced until now. Although sequences from model teleost fish genomes are a valuable tool for comparative approaches to elucidate the genomics of phylogenetically related non-model teleost [14-17], they are selected for the opposite reasons of aquaculture species, which generally have large body mass and long reproductive cycles. 
The European sea bass Dicentrarchus labrax L. (Moronidae, Perciformes, Teleostei) is a major fisheries and aquaculture species in the Mediterranean and Atlantic coasts of Europe and North Africa. Its industrial production has steadily grown over the past two decades and in 2008 it reached at least 105,900 metric tonnes http://www.globefish.org. Worldwide, basses and other perciform fish, which include the tunas, breams and tilapias, account for over $3.5 \times 10^{6}$ metric tonnes and USD $7 \times 10^{9}$ [18]. With the need to feed a growing population, an interest in healthy foods and the collapse of wild fisheries stocks, aquaculture has acquired a great importance $[19,20]$. Intensification of fish cultivation has largely targeted selection of faster growth rates and better feed conversion ratios. Fish feeds rely heavily on wild caught fish meal and oils, which puts further pressure on fish stocks and are a source of eutrophying pollutants [19-21]. The development of cultivation methods and new strains with increased productivity but at the same time the ability to digest alternative sources from plant material are therefore desirable objectives of the industry. They should decrease the dependency on capture fisheries [22]. Other objectives are strains with improved resistance to pathogens and tolerance to stress [23]. However, and although classical selection methods have an important role to play, genomic technologies can improve the genetic and biological basis of traits and allow direct selection on the genotype [23].

Economic and resource management interests have led to increased research efforts to develop genomics resources for European sea bass [24,25], including a >12 $\times$ coverage BAC-library [26], hundreds of microsatellite [27] and SNP markers [28], ESTs (Passos et al., unpublished), a genetic linkage map [29,30] and a radiation hybrid map (Senger, Galibert et al., unpublished). The European sea bass nuclear DNA content has been estimated at $1.55-1.58 \mathrm{pg}$ [31] approximately twice that of $T$. rubripes [32], which, despite of advances in sequencing technologies, remains a large financial and logistic hurdle.

With time strategies for full de novo sequencing of large eukaryote genomes have shifted from whole genome shotgun (WGS) Sanger sequencing of cloned genomic DNA [8] to a combination of mapped large insert clone and WGS sequencing $[33,34]$. Today, with the evolution of second generation sequencing technologies, the re-sequencing of eukaryote genomes by massive parallel WGS sequencing is feasible [35]. It is expected that second generation sequencing technologies and especially pyrosequencing, which has been shown to cut costs and speedup the de novo sequencing of microbial genomes [36] will further contribute to reducing costs and time to sequence large genomes of higher eukaryotes.
In a pilot study for sequencing the genome of Atlantic salmon (Salmo salar) by Quinn et al. [37] pyrosequencing was useful for the generation of a draft sequence of a megabase sized genomic region. It also turned out that repeat richness in eukaryote genomes is the major problem for de novo sequencing with second generation technologies. Sequence-repeats resulted in a large amount of gaps in the assembly as they could not be resolved with reads shorter than the repeat itself, even if paired-end tags were used to scaffold the assembled contigs. A "first map, then sequence" strategy improves this situation as large genomes can be split into smaller subunits, which is one argument for genome mapping with large insert clones. Moreover hybrid assembly of Sanger sequencing data and short read data benefits from both technologies, finding a good balance of cost and quality [38].

Here we describe a comparative BAC-map and low coverage draft of the European sea bass genome obtained by high-throughput Sanger-sequencing of BAC-libraries and whole genome shotgun plasmid libraries as well as the exploitation of the synteny between D. labrax and G. aculeatus. The dataset represents the first whole genome sequencing of a fish belonging to the order of Perciformes and of a cultivated fish species, and sets the basic conditions for complete genome sequencing by second generation techniques in the near future.

\section{Results}

\section{BAC-end sequencing}

After quality clipping (> 300 Q20 bases) and removal of vector contamination, 102,690 BAC-end sequences (ES) with an average read length of 670 bp remained for analysis (sequences were submitted to EMBL nucleotide database [EMBL:FN436279 - EMBL:FN538968]. For a total of 44,836 BAC-clones, paired end sequences (BACES) were determined, while for 13,018 BAC-clones only one ES was obtained. The estimated genome size of $D$. labrax based on diploid nuclear DNA content [31] is approximately $763 \mathrm{Mbp}$, suggesting that with an average insert size of $164 \mathrm{kbp}$ per BAC, the genome coverage of paired end-sequenced BACs is about 9.6 fold. Clones that were sequenced only from one side sum up to an additional 2.8 fold genome coverage (see Table 1).

For comparative mapping, a subset of 10,000 BAC-ES was chosen to perform BLASTN searches with an evalue cut-off of $1 \mathrm{e}^{-5}$ against the genomes of $D$. rerio [10], T. nigroviridis [7]], O. latipes [9] and G. aculeatus http://www.ensembl.org. The genomic sequence of $T$. rubripes [8]] was not used as the genome assembly has not been assigned to chromosomes. The highest number of matches was obtained against G. aculeatus (4,359 ES matches), followed by O. latipes $(2,702), T$. nigroviridis 
Table 1 BAC end sequencing results.

\begin{tabular}{ccccc}
\hline & both ends & only forward & only reverse & total \\
\hline BACs with good seq. & 44,836 & 7,235 & 5,783 & 57,854 \\
\hline sequencing coverage [bp] & $60,073,046$ & $4,846,870$ & $3,874,146$ & $68,794,062$ \\
\hline physical coverage [x-fold] & 9.6 & 1.6 & 1.2 & 12.4 \\
\hline
\end{tabular}

The physical coverage was calculated by conservatively estimating a genome size of $763 \mathrm{Mbp}$ for sea bass and an average BAC insert size of $164 \mathrm{kbp}$.

$(2,536)$ and $D$. rerio $(1,128)$. The results reflect known phylogenies, with $D$. rerio (superorder Ostariophysii) distantly related to the other candidates (all from the superorder Acanthopterygii) [39].

\section{Whole genome shotgun sequencing}

Sequencing of whole genome shotgun libraries yielded $>2$ $\times 10^{6}$ reads with an average Q20 read length of $673 \mathrm{bp}$ comprising $\sim 1.4 \mathrm{Gbp}$ and approximately twofold coverage of the D. labrax genome. Assembly of WGS-reads and BAC-ES yielded 273,453 contigs and 217,926 singlets covering $~ 580 \mathrm{Mbp}$. The N50 contig size was 2,891 bp and the largest contig was $15,629 \mathrm{bp}$. A part of this dataset, namely 36,166 contigs were useful to anchor additional BAC-ES to the stickleback genome (see below). These contigs have been submitted to EMBL nucleotide database [EMBL:CABK01000001 - EMBL:CABK01036166].

\section{Comparative mapping}

The whole BAC-ES dataset was aligned with the fully assembled stickleback genome. Further sorting and screening yielded 25,845 BAC-ES where only one end was sequenced or matched the stickleback genome and 13,996 BACs matched both ends to the same chromosome in stickleback. 18,013 BACs were matching weakly and were excluded (mostly due to repetitive motifs or possible chimeric BACs). BACs with both ES aligned were essential for comparative mapping and could be subdivided into 12,076 BACs with correct orientation and distance of aligned ES and 1,920 BACs not matching these consistency criteria due to possible rearrangements, miss-alignments or assembly failures in the stickleback genome. Plotting the frequency distribution of insert size of consistently mapped BACs resulted in a Gaussian-like distribution with a maximum at $115 \mathrm{kbp}$. This reflects a compression of the stickleback genome compared to the D. labrax genome, as the average insert size published for D. labrax is about 164 kbp [26] (see Fig. 1).

D. labrax BACs that were consistently positioned in the stickleback genome were used to calculate a minimal tiling path of overlapping BAC-clones resulting in 816 BAC-contigs that cover $78.1 \%$ of the $400.8 \mathrm{Mbp}$ stickleback chromosomes and consisted of 3,629 BACs.
The minimal tiling path of the largest BAC-contig comprised 52 BACs and covered 5.03 Mbp on G. aculeatus linkagegroup VI. N50 BAC-contig size was $0.53 \mathrm{Mbp}$. In the chromosomal regions covered by comparatively mapped BACs $77.5 \%$ of annotated genes assigned to stickleback chromosomes can be found (see Table 2, Table 3 and Table 4/values in brackets).

Comparative mapping was improved by aligning BACES containing contigs from the WGS and BAC-ES assembly to stickleback chromosomes. This strategy yielded 20,635 BACs matching consistency criteria, an improvement of about $71 \%$ compared to comparative mapping using only BAC-ES data. The re-calculated minimal tiling path reduced total contig number to 588 and N50 contig number to 83 while increasing N50 BAC-contig size to $1.2 \mathrm{Mbp}$ and coverage of stickleback chromosomes to $87 \%$ (see Table 2, Table 3, Table 4 and Fig. 2, a complete list of ordered paired-end aligned BAC clones on stickleback chromosomes may be downloaded [Additional file 1]).

Moreover the higher coverage with BACs enabled the identification of potential intra-chromosomal rearrangements between sea bass and stickleback (or failures in the stickleback assembly). A number of 214 potential chromosomal breakpoints spanned by BAC-clones were identified [Additional file 2]. To check if rearrangements were artefacts, the order of calculated BAC-contigs was cross-checked by alignment to the medaka genome (see Fig. 3). In total 139 cases (65\%), had a neighbouring position at that site and thus confirmed the consistency of the identified BAC-clone on the second reference genome.

Fig. 4 shows PCR results that support the bioinformatic data on rearrangements between sea bass and stickleback. All of the seven rearrangements that were checked by PCR have been confirmed. For each of these rearrangements we found at least $2 \mathrm{BAC}$ clones that gave positive results in the $\mathrm{PCR}$, the average number of $\mathrm{BAC}$ clones spanning a rearrangement was 4.6 and the maximum number was 7 clones.

The consistently mapped BACs were also uploaded to the Ensembl genome browser and may be viewed in a user friendly format alongside the annotated stickleback chromosomes (see Fig. 5) 


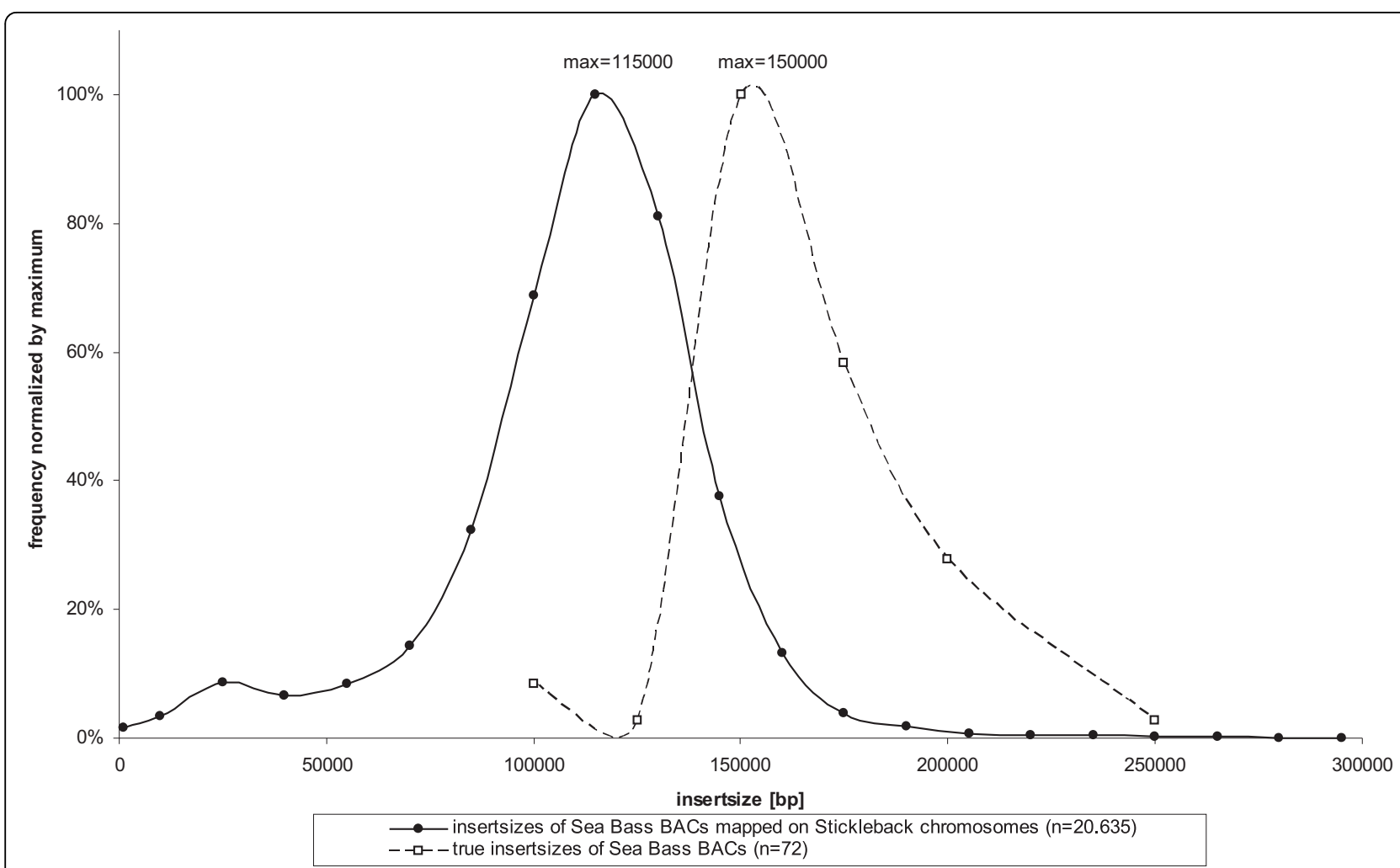

Figure 1 Comparison of BAC insert size frequency distributions. Insert sizes calculated by sea bass BAC-ES, consistently mapped to stickleback chromosomes, show a shift to lower insert sizes compared to the observed insert size of the library published by Whitaker et al. [26]. This observation can be explained by genome size evolution in teleosts. As the genome of sea bass is known to be larger than the stickleback genome the lower insert size of mapped BACs reflects the average size difference of orthologous loci. By dividing the insert sizes at the maxima of the distributions, it can be concluded that the sea bass genome is about 1.3 fold larger than the stickleback genome.

\section{Discussion}

Recently BAC-end sequencing has been a tool for scaffolding large eukaryotic genome assemblies and thus became important in the final phase of sequencing projects. Today as the number of eukaryotic genomes in the databases is steadily increasing, comparative mapping approaches will change that picture. In the case of Dicentrarchus labrax BAC-end sequencing started before a whole genome project was even planned and enabled a fast and cost-effective mapping of the genome.

\section{Comparative mapping compared to other mapping strategies}

Since publication of the first BAC-vector [40] several strategies for the construction of physical genome maps from BAC-libraries have been published. Among these methods BAC-filter hybridization [41], BAC-fingerprinting [42] and PCR screening [43] have been applied most frequently. Comparative mapping approaches are likely to replace these methods because many genomes of higher eukaryotes have been published. Comparative maps are built by aligning paired end sequences of large insert clones (e.g. BACs) to a reference genome and thus detecting possible overlaps of clones that subsequently can be combined into contigs. This strategy has been successfully applied to closely related organisms such as chimpanzee and human [44] and also to more distantly related organisms like cattle and human [45]. Comparative mapping has some advantages for automated analysis over the methods mentioned above, as established pipelines for high-throughput sequencing and bioinformatics can be used.

\section{BAC end sequencing results}

Sanger sequencing of BAC-ends remains restricted to a 96 well format in many sequencing centers, because of low template yields and large amounts of template used for the sequencing reactions. Thus the successful development of an automated DNA purification process to purify BAC-DNA from 384 well plates was a crucial step to enable the comparative genome mapping of $D$. labrax. With an average read length of $650 \mathrm{bp}$ on 36 $\mathrm{cm}$ and $750 \mathrm{bp}$ on $50 \mathrm{~cm}$ capillaries the read length of BAC-end sequences was substantially higher than reported in comparable projects [45]. Failed reactions were less than $11 \%$. 
Table 2 Mapping statistics for sea bass BAC-ES comparatively mapped to the stickleback chromosomes I to VII.

\begin{tabular}{|c|c|c|c|c|c|c|c|c|c|}
\hline \multirow[t]{3}{*}{ A } & stickleback chromosome & ALL CHR & CHR I & CHR II & CHR III & CHR IV & CHR V & CHR VI & CHR VII \\
\hline & stickleback chromosome size [bp] & $400,788,495$ & $28,185,914$ & $23,295,652$ & $16,798,506$ & $32,632,948$ & $12,251,397$ & $17,083,675$ & $27,937,443$ \\
\hline & genetic linkage group sea bass & - & LG13 & LG5 & LG10 & $L G 2 / ?$ & LG1 & LG11 & LG3/LG14 \\
\hline \multirow[t]{6}{*}{$B$} & sea bass BAC-contigs & $\begin{array}{l}588 \\
(816)\end{array}$ & $\begin{array}{c}34 \\
(58)\end{array}$ & $\begin{array}{l}28 \\
(44)\end{array}$ & $\begin{array}{c}24 \\
(29)\end{array}$ & $\begin{array}{l}42 \\
(62)\end{array}$ & $\begin{array}{c}16 \\
(28)\end{array}$ & $\begin{array}{c}24 \\
(36)\end{array}$ & $\begin{array}{c}43 \\
(65)\end{array}$ \\
\hline & largest BAC-contig [bp] & $\begin{array}{c}8,860,934 \\
(5,034,967)\end{array}$ & $\begin{array}{c}6,029,661 \\
(4,511,889)\end{array}$ & $\begin{array}{c}4,235,816 \\
(2,100,554)\end{array}$ & $\begin{array}{c}3,575,021 \\
(2,455,450)\end{array}$ & $\begin{array}{c}7,720,774 \\
(3,886,881)\end{array}$ & $\begin{array}{c}1,931,357 \\
(1,573,884)\end{array}$ & $\begin{array}{c}8,860,934 \\
(5,034,967)\end{array}$ & $\begin{array}{c}4,327,197 \\
(2,521,767)\end{array}$ \\
\hline & $\%$ of chr. covered by BAC-contigs & $\begin{array}{c}87.0 \% \\
(78.1 \%)\end{array}$ & $\begin{array}{c}84.8 \% \\
(75.6 \%)\end{array}$ & $\begin{array}{c}90.0 \% \\
(83.6 \%)\end{array}$ & $\begin{array}{c}85.5 \% \\
(76.0 \%)\end{array}$ & $\begin{array}{c}86.6 \% \\
(76.2 \%)\end{array}$ & $\begin{array}{c}88.5 \% \\
(83.4 \%)\end{array}$ & $\begin{array}{c}85.3 \% \\
(77.5 \%)\end{array}$ & $\begin{array}{c}89.3 \% \\
(78.9 \%)\end{array}$ \\
\hline & number of BACs in min. tiling path & $3,929(3,629)$ & $271(257)$ & $227(221)$ & $161(144)$ & $313(283)$ & $121(118)$ & $162(147)$ & $281(266)$ \\
\hline & paired end aligned consistent BACs & $\begin{array}{c}20,635 \\
(12,076)\end{array}$ & $1,465(802)$ & $1,254(772)$ & $874(510)$ & $1,593(883)$ & $731(418)$ & $993(678)$ & $1,486(849)$ \\
\hline & one end aligned BACs & $\begin{array}{c}24,940 \\
(25,845)\end{array}$ & $\begin{array}{c}1,759 \\
(1,781)\end{array}$ & $\begin{array}{c}1,399 \\
(1,453)\end{array}$ & $\begin{array}{c}1,199 \\
(1,196)\end{array}$ & $\begin{array}{c}2,012 \\
(2,111)\end{array}$ & $784(839)$ & $\begin{array}{c}1,052 \\
(1,087)\end{array}$ & $\begin{array}{c}1,855 \\
(1,940)\end{array}$ \\
\hline \multirow[t]{4}{*}{ C } & inconsistently aligned same chr. & $\begin{array}{c}1,487 \\
(1,920)\end{array}$ & $\begin{array}{c}98 \\
(128)\end{array}$ & $\begin{array}{c}77 \\
(100)\end{array}$ & $\begin{array}{c}93 \\
(128)\end{array}$ & $\begin{array}{c}111 \\
(152)\end{array}$ & $\begin{array}{l}57 \\
(80)\end{array}$ & $\begin{array}{l}64 \\
(96)\end{array}$ & $\begin{array}{c}97 \\
(132)\end{array}$ \\
\hline & $\begin{array}{l}\text { potential intra-chr. rearrangements } \\
\text { between stickleback and sea bass }\end{array}$ & 214 & 12 & 8 & 17 & 10 & 6 & 9 & 14 \\
\hline & $\begin{array}{l}\text { intra-chr. rearrangements also found } \\
\text { between medaka and stickleback }\end{array}$ & 139 & 9 & 5 & 17 & 8 & 2 & 1 & 10 \\
\hline & $\begin{array}{l}\text { BAC-contigs with same neighbour in } \\
\text { medaka as in stickleback }\end{array}$ & 149 & 7 & 4 & 4 & 16 & 4 & 7 & 7 \\
\hline \multirow[t]{2}{*}{$\mathrm{D}$} & total annotated genes in ensembl & 19,045 & 1,253 & 853 & 923 & 1,317 & 733 & 749 & 1,311 \\
\hline & $\%$ genes covered by BAC-contigs & $\begin{array}{l}85.4 \% \\
(77.5 \%)\end{array}$ & $\begin{array}{l}80.5 \% \\
(73.9 \%)\end{array}$ & $\begin{array}{l}85.2 \% \\
(78.8 \%)\end{array}$ & $\begin{array}{l}86.5 \% \\
(79.2 \%)\end{array}$ & $\begin{array}{l}88.3 \% \\
(79.3 \%)\end{array}$ & $\begin{array}{l}88.4 \% \\
(83.2 \%)\end{array}$ & $\begin{array}{l}78.2 \% \\
(72.0 \%)\end{array}$ & $\begin{array}{l}86.7 \% \\
(76.1 \%)\end{array}$ \\
\hline
\end{tabular}

Rows (A) show a summary of the 21 reference chromosomes (stickleback assembly: BROAD S1, Feb 2006) and the known corresponding genetic linkage groups of sea bass according to Chistiakov et al. [30]. Rows (B) summarize consistently mapped BAC-ES, BAC-contigs and reference genome/chromosome coverage of the minimal tiling path. Rows (C) focus on inconsistently mapped BAC-ES, which where further analysed for potential intra-chromosomal rearrangements and compared to the medaka genome as a second reference genome. Rows (D) display the number of annotated genes in stickleback and the percentage of them covered by the sea bass BAC-map. Values in brackets "()" show results for a comparative map that was built by using only BAC-ES data, while all other values represent results of improved mapping using BAC-ES together with whole genome shotgun data.

\section{Reference genomes}

Besides read quality, the choice of a suitable reference genome is influencing mapping success and quality. Several sequenced genomes of model teleosts are available (e.g. D. rerio, T. nigroviridis, T. rubripes, O. latipes and G. aculeatus). With the highest number of mappable reads, the stickleback genome sequences shared the highest homology to D. labrax, making it the genome of choice for a comparative approach. The stickleback and the European sea bass belong to the superorder Percomorpha, and the evolutionary related orders of Gasterosteiformes and Perciformes, respectively [46]. Additional beneficial features of the stickleback genome sequence is the high sequencing coverage ( $\sim 12$ fold) and the mapping of most scaffolds to chromosomes.

\section{The comparative map}

After BAC-ES data for sea bass became available, a first comparative BAC-map was built. Results were already usable to render megabase sized contigs and to screen for BACs covering genes of interest. Subsequently with a WGS dataset of the sea bass genome available, BAC-ES sequences and WGS data were combined by assembly. If a BAC-ES alone could not be matched with the reference earlier on, the length extension of the BAC-ES by aligned WGS reads now increased the probability to find matches with good alignments to the reference genome. Final mapping (Fig. 2) shows in green that most of stickleback chromosomes are covered by D. labrax BACs with consistent orientation and distance $(87 \%$ of reference genome), while red regions have a weak mapping, where no or only one BAC-end sequence could be matched. These regions may be either due to highly repetitive fragments, gaps and/or failures in the assembly of the sticklebackgenomic sequence or regions that are underrepresented in the BAC-library. It is obvious that especially centromeric and telomeric regions, known for the problems mentioned above, account for weakly mapped regions.

\section{Calculating the genome size of $D$. labrax}

When comparing the insert size distribution of consistently mapped BACs on the reference genome with the published insert size distribution of the D. labrax BAClibrary (Fig. 1), a shift to lower insert sizes is observed. 
Table 3 Mapping statistics for sea bass BAC-ES comparatively mapped to the stickleback chromosomes VIII to XIV.

\begin{tabular}{|c|c|c|c|c|c|c|c|c|}
\hline \multirow[t]{3}{*}{$A$} & stickleback chromosome & CHR VIII & CHR IX & CHR X & CHR XI & CHR XII & CHR XIII & CHR XIV \\
\hline & stickleback chromosome size [bp] & $19,368,704$ & $20,249,479$ & $15,657,440$ & $16,706,052$ & $18,401,067$ & $20,083,130$ & $15,246,461$ \\
\hline & genetic linkage group sea bass & LG4 & LG7 & LG9 & LG8 & $?$ & LG20 & LG19 \\
\hline \multirow[t]{6}{*}{$B$} & sea bass BAC-contigs & $\begin{array}{c}30 \\
(44)\end{array}$ & $\begin{array}{c}37 \\
(45)\end{array}$ & $\begin{array}{c}31 \\
(37)\end{array}$ & $\begin{array}{c}30 \\
(27)\end{array}$ & $\begin{array}{l}27 \\
(35)\end{array}$ & $\begin{array}{c}26 \\
(38)\end{array}$ & $\begin{array}{c}18 \\
(33)\end{array}$ \\
\hline & largest BAC-contig [bp] & $\begin{array}{c}4,711,769 \\
(3,129,353)\end{array}$ & $\begin{array}{c}3,058,355 \\
(1,487,429)\end{array}$ & $\begin{array}{c}1,368,409 \\
(1,368,348)\end{array}$ & $\begin{array}{c}4,014,839 \\
(3,993,770)\end{array}$ & $\begin{array}{c}4,710,925 \\
(2,950,196)\end{array}$ & $\begin{array}{c}3,478,171 \\
(3,182,188)\end{array}$ & $\begin{array}{c}3,545,956 \\
(1,757,446)\end{array}$ \\
\hline & $\%$ of chr. covered by BAC-contigs & $\begin{array}{l}85.8 \% \\
(77.0 \%)\end{array}$ & $\begin{array}{l}82.9 \% \\
(69.7 \%)\end{array}$ & $\begin{array}{l}84.2 \% \\
(75.4 \%)\end{array}$ & $\begin{array}{l}83.3 \% \\
(74.4 \%)\end{array}$ & $\begin{array}{l}88.5 \% \\
(78.1 \%)\end{array}$ & $\begin{array}{c}90.6 \% \\
(81.8 \%)\end{array}$ & $\begin{array}{l}88.0 \% \\
(77.5 \%)\end{array}$ \\
\hline & number of BACs in min. tiling path & $\begin{array}{c}188 \\
(177)\end{array}$ & $\begin{array}{c}195 \\
(174)\end{array}$ & $\begin{array}{c}152 \\
(140)\end{array}$ & $\begin{array}{c}155 \\
(147)\end{array}$ & $\begin{array}{c}177 \\
(160)\end{array}$ & $\begin{array}{c}194 \\
(176)\end{array}$ & $\begin{array}{c}150 \\
(142)\end{array}$ \\
\hline & paired end aligned consistent BACs & $\begin{array}{c}869 \\
(517)\end{array}$ & $\begin{array}{c}855 \\
(448)\end{array}$ & $\begin{array}{l}712 \\
(410)\end{array}$ & $\begin{array}{c}816 \\
(494)\end{array}$ & $\begin{array}{c}902 \\
(559)\end{array}$ & $\begin{array}{l}1,121 \\
(678)\end{array}$ & $\begin{array}{l}792 \\
(414)\end{array}$ \\
\hline & one end aligned BACs & $\begin{array}{c}1,002 \\
(1,190) \\
\end{array}$ & $\begin{array}{c}1,190 \\
(1,168) \\
\end{array}$ & $\begin{array}{c}897 \\
(879) \\
\end{array}$ & $\begin{array}{c}1,101 \\
(1,089) \\
\end{array}$ & $\begin{array}{c}1,211 \\
(1,364) \\
\end{array}$ & $\begin{array}{c}1,194 \\
(1,266) \\
\end{array}$ & $\begin{array}{c}931 \\
(1,017) \\
\end{array}$ \\
\hline \multirow[t]{4}{*}{$\mathrm{C}$} & inconsistently aligned same chr. & $\begin{array}{c}110 \\
(112)\end{array}$ & $\begin{array}{c}84 \\
(90)\end{array}$ & $\begin{array}{c}90 \\
(118)\end{array}$ & $\begin{array}{c}81 \\
(86)\end{array}$ & $\begin{array}{c}58 \\
(90)\end{array}$ & $\begin{array}{c}42 \\
(80)\end{array}$ & $\begin{array}{c}59 \\
(62)\end{array}$ \\
\hline & $\begin{array}{l}\text { potential intra-chr. rearrangements } \\
\text { between stickleback and sea bass }\end{array}$ & 10 & 12 & 16 & 13 & 12 & 9 & 6 \\
\hline & $\begin{array}{l}\text { intra-chr. rearrangements also found } \\
\text { between medaka and stickleback }\end{array}$ & 5 & 9 & 13 & 7 & 9 & 3 & 2 \\
\hline & $\begin{array}{l}\text { BAC-contigs with same neighbour in } \\
\text { medaka as in stickleback }\end{array}$ & 15 & 12 & 6 & 8 & 6 & 7 & 9 \\
\hline \multirow[t]{2}{*}{$\mathrm{D}$} & total annotated genes in ensembl & 876 & 1,009 & 802 & 1,050 & 1,000 & 970 & 738 \\
\hline & $\%$ genes covered by BAC-contigs & $\begin{array}{l}83.4 \% \\
(75.9 \%)\end{array}$ & $\begin{array}{l}80.0 \% \\
(70.5 \%)\end{array}$ & $\begin{array}{l}81.2 \% \\
(70.7 \%)\end{array}$ & $\begin{array}{l}83.5 \% \\
(75.3 \%)\end{array}$ & $\begin{array}{l}86.8 \% \\
(76.5 \%)\end{array}$ & $\begin{array}{l}89.6 \% \\
(81.6 \%)\end{array}$ & $\begin{array}{l}85.2 \% \\
(74.9 \%)\end{array}$ \\
\hline
\end{tabular}

Rows (A) show a summary of the 21 reference chromosomes (stickleback assembly: BROAD S1, Feb 2006) and the known corresponding genetic linkage groups of sea bass according to Chistiakov et al. [30]. Rows (B) summarize consistently mapped BAC-ES, BAC-contigs and reference genome/chromosome coverage of the minimal tiling path. Rows (C) focus on inconsistently mapped BAC-ES, which where further analysed for potential intra-chromosomal rearrangements and compared to the medaka genome as a second reference genome. Rows (D) display the number of annotated genes in stickleback and the percentage of them covered by the sea bass BAC-map. Values in brackets "()" show results for a comparative map that was built by using only BAC-ES data, while all other values represent results of improved mapping using BAC-ES together with whole genome shotgun data.

An explanation for this may be found in the evolution of genome size. It has been shown that teleost genomes tend to accumulate most indels in intergenic or intronic regions leading towards large differences in genome size, while synteny of genes is conserved [47]. Thus one may conclude that the ratio of the maxima in the insert size distributions of BAC-clones equals the ratio of genome sizes. From this calculation one may conclude that the D. labrax genome is about 1.3 fold larger than the 460 Mbp of the G. aculeatus genome. The calculated haploid genome size of $600 \mathrm{Mbp}$ is smaller than the estimated haploid genome size of $763 \mathrm{Mbp}$ derived from flow cytometric measurements of diploid nuclear DNA content [31]. A smaller genome size is also suggested by the first assembly of our twofold coverage WGS dataset (see WGS sequencing results). Nevertheless, genome size estimates from sequencing may be biased towards the euchromatic portion of the genomes and different results of the methods may be explained by underrepresentation or different size evolution of heterochromatic regions.

\section{Comparing the BAC and the linkage map of $D$. labrax}

BAC contigs represented by green regions in Fig. 2 are considered blocks with a high level of synteny between D. labrax and G. aculeatus. Nevertheless it is questionable whether neighbouring BAC-contigs on the reference genome are really neighbours in the D. labrax genome or whether chromosomes have undergone extensive interchromosomal rearrangements during evolution. To decide either whether a rearrangement has taken place or the order of BAC-contigs is consistent in both genomes, it is helpful to compare results from the D. labrax genetic linkage map and the radiation hybrid map of the closely related sparid Sparus aurata (gilthead sea bream). Such comparisons with stickleback have been done by Chistiakov et al. [30] and Sarropoulou et al. [16] and showed synteny of complete chromosomes between these species. Chromosome identity and re-shuffling are common features among closely related organisms. The different chromosome number of $G$. aculeatus $(\mathrm{n}=21)$ and $D$. labrax $(\mathrm{n}=24)$ is a common feature between related taxa and can be explained by fusions/fissions of complete 
Table 4 Mapping statistics for sea bass BAC-ES comparatively mapped to the stickleback chromosomes XV to XXI.

\begin{tabular}{|c|c|c|c|c|c|c|c|c|}
\hline \multirow[t]{3}{*}{ A } & stickleback chromosome & CHR XV & CHR XVI & CHRXVII & CHRXVIII & CHRXIX & CHR XX & CHR XXI \\
\hline & stickleback chromosome size [bp] & $16,198,764$ & $18,115,788$ & $14,603,141$ & $16,282,716$ & $20,240,660$ & $19,732,071$ & $11,717,487$ \\
\hline & genetic linkage group sea bass & LG13 & LG15 & LG1? & LG17 & LG6 & LG16/18? & LG18? \\
\hline \multirow[t]{6}{*}{ B } & sea bass BAC-contigs & $\begin{array}{c}20 \\
(29)\end{array}$ & $\begin{array}{c}24 \\
(38)\end{array}$ & $\begin{array}{c}30 \\
(30)\end{array}$ & $\begin{array}{c}35 \\
(43)\end{array}$ & $\begin{array}{c}38 \\
(43)\end{array}$ & $\begin{array}{c}22 \\
(35)\end{array}$ & $\begin{array}{c}9 \\
(17)\end{array}$ \\
\hline & largest BAC-contig [bp] & $\begin{array}{c}3,426,120 \\
(1,723,928)\end{array}$ & $\begin{array}{c}6,616,511 \\
(2,444,746)\end{array}$ & $\begin{array}{c}3,516,936 \\
(2,019,946)\end{array}$ & $\begin{array}{c}1,934,982 \\
(1,280,086)\end{array}$ & $\begin{array}{c}2,450,075 \\
(2,125,025)\end{array}$ & $\begin{array}{c}7,220,725 \\
(2,296,377)\end{array}$ & $\begin{array}{c}4,139,228 \\
(2,305,187)\end{array}$ \\
\hline & $\%$ of chr. covered by BAC-contigs & $\begin{array}{l}89.3 \% \\
(82.5 \%)\end{array}$ & $\begin{array}{c}88.4 \% \\
(79.0 \%)\end{array}$ & $\begin{array}{c}88.5 \% \\
(78.7 \%)\end{array}$ & $\begin{array}{c}83.6 \% \\
(70.6 \%)\end{array}$ & $\begin{array}{l}86.6 \% \\
(78.2 \%)\end{array}$ & $\begin{array}{c}90.3 \% \\
(82.8 \%)\end{array}$ & $\begin{array}{l}87.4 \% \\
(83.3 \%)\end{array}$ \\
\hline & number of BACs in min. tiling path & $\begin{array}{c}156 \\
(150)\end{array}$ & $\begin{array}{c}182 \\
(167)\end{array}$ & $\begin{array}{c}163 \\
(138)\end{array}$ & $\begin{array}{c}170 \\
(143)\end{array}$ & $\begin{array}{l}206 \\
(185)\end{array}$ & $\begin{array}{c}194 \\
(178)\end{array}$ & $\begin{array}{c}111 \\
(116)\end{array}$ \\
\hline & paired end aligned consistent BACs & $\begin{array}{c}969 \\
(619) \\
\end{array}$ & $\begin{array}{c}916 \\
(533) \\
\end{array}$ & $\begin{array}{c}784 \\
(459) \\
\end{array}$ & $\begin{array}{c}783 \\
(373) \\
\end{array}$ & $\begin{array}{l}1,004 \\
(628) \\
\end{array}$ & $\begin{array}{l}1,077 \\
(639) \\
\end{array}$ & $\begin{array}{c}639 \\
(393) \\
\end{array}$ \\
\hline & one end aligned BACs & $\begin{array}{c}1,017 \\
(1,057)\end{array}$ & $\begin{array}{c}1,163 \\
(1,162)\end{array}$ & $\begin{array}{c}1,110 \\
(1,145)\end{array}$ & $\begin{array}{c}989 \\
(1,040)\end{array}$ & $\begin{array}{c}1,204 \\
(1,187)\end{array}$ & $\begin{array}{c}1,178 \\
(1,183)\end{array}$ & $\begin{array}{l}693 \\
(691)\end{array}$ \\
\hline \multirow[t]{4}{*}{ C } & inconsistently aligned same chr. & $\begin{array}{l}73 \\
(96)\end{array}$ & $\begin{array}{l}47 \\
(74)\end{array}$ & $\begin{array}{c}37 \\
(34)\end{array}$ & $\begin{array}{l}68 \\
(78)\end{array}$ & $\begin{array}{c}104 \\
(128)\end{array}$ & $\begin{array}{c}30 \\
(46)\end{array}$ & $\begin{array}{c}7 \\
(10)\end{array}$ \\
\hline & $\begin{array}{l}\text { potential intra-chr. rearrangements } \\
\text { between stickleback and sea bass }\end{array}$ & 10 & 8 & 6 & 12 & 14 & 8 & 2 \\
\hline & $\begin{array}{l}\text { intra-chr. rearrangements also found } \\
\text { between medaka and stickleback }\end{array}$ & 9 & 4 & 4 & 6 & 8 & 6 & 2 \\
\hline & $\begin{array}{l}\text { BAC-contigs with same neighbour in } \\
\text { medaka as in stickleback }\end{array}$ & 3 & 7 & 4 & 9 & 7 & 3 & 4 \\
\hline \multirow[t]{2}{*}{$\mathrm{D}$} & total annotated genes in ensembl & 779 & 799 & 698 & 761 & 1,037 & 927 & 460 \\
\hline & $\%$ genes covered by BAC-contigs & $\begin{array}{l}87.9 \% \\
(84.1 \%)\end{array}$ & $\begin{array}{l}88.5 \% \\
(80.4 \%)\end{array}$ & $\begin{array}{l}85.5 \% \\
(77.4 \%)\end{array}$ & $\begin{array}{l}82.7 \% \\
(69.5 \%)\end{array}$ & $\begin{array}{l}82.5 \% \\
(75.5 \%)\end{array}$ & $\begin{array}{l}89.5 \% \\
(85.1 \%)\end{array}$ & $\begin{array}{l}93.9 \% \\
(86.7 \%)\end{array}$ \\
\hline
\end{tabular}

Rows (A) show a summary of the 21 reference chromosomes (stickleback assembly: BROAD S1, Feb 2006) and the known corresponding genetic linkage groups of sea bass according to Chistiakov et al. [30]. Rows (B) summarize consistently mapped BAC-ES, BAC-contigs and reference genome/chromosome coverage of the minimal tiling path. Rows (C) focus on inconsistently mapped BAC-ES, which where further analysed for potential intra-chromosomal rearrangements and compared to the medaka genome as a second reference genome. Rows (D) display the number of annotated genes in stickleback and the percentage of them covered by the sea bass BAC-map. Values in brackets "()" show results for a comparative map that was built by using only BAC-ES data, while all other values represent results of improved mapping using BAC-ES together with whole genome shotgun data.

orthologous groups. Thus it is unlikely that BAC-contigs mapped to one G. aculeatus chromosome are not located on a single D. labrax chromosome. These results also allow assigning the comparatively mapped BAC-contigs to D. labrax linkage groups (Table $2 \mathrm{~A}$, Table $3 \mathrm{~A}$ and Table 4A).

Comparison of the D. labrax linkage map with the $G$. aculeatus genome has suggested some intra-chromosomal rearrangements [30]. Due to the higher resolution of the comparative BAC-map, it is possible to pinpoint potential rearrangements by focussing on inconsistently mapped BACs that connect two BAC-contigs at their boundary regions. Since BAC-libraries are known to harbour some chimeric clones, the location of potentially neighbouring BAC-contigs was confirmed by cross-checking their position in the medaka genome. If BAC-contigs connected by a rearrangement spanning $\mathrm{BAC}$ were located next to each other in the medaka genome, a true rearrangement was considered (Fig. 3). In this way 139 BACs spanning rearrangements between the reference and $D$. labrax genome were identified. Seven rearrangements between chr III of stickleback and the corresponding sea bass linkage group 10 were also tested by means of PCR. All of them could be confirmed (Fig. 4).

\section{Applications}

The main advantage of BAC-maps over other mapping methods, like genetic linkage maps or radiation hybrid maps, is the possibility to access defined portions of a genome for subsequent analysis by common methods of molecular genetics. As the comparative BAC-map covers about $85.4 \%$ of predicted $G$. aculeatus genes, it is now possible to easily access orthologous $D$. labrax genes by selecting a BAC-clone that covers the genomic region of interest. As proof of principle, we have successfully identified and shotgun sequenced 10 overlapping BACclones that cover a $1.3 \mathrm{Mbp}$ genomic region on sea bass linkage group 5 (Negrisolo et al. in preparation). The BAC map was also used to analyze two clones that contain a novel immune-type receptor (NITR) gene cluster [48] and to sequence the fatty acid delta-6 desaturase gene in European sea bass (Santigosa et al. in preparation). 


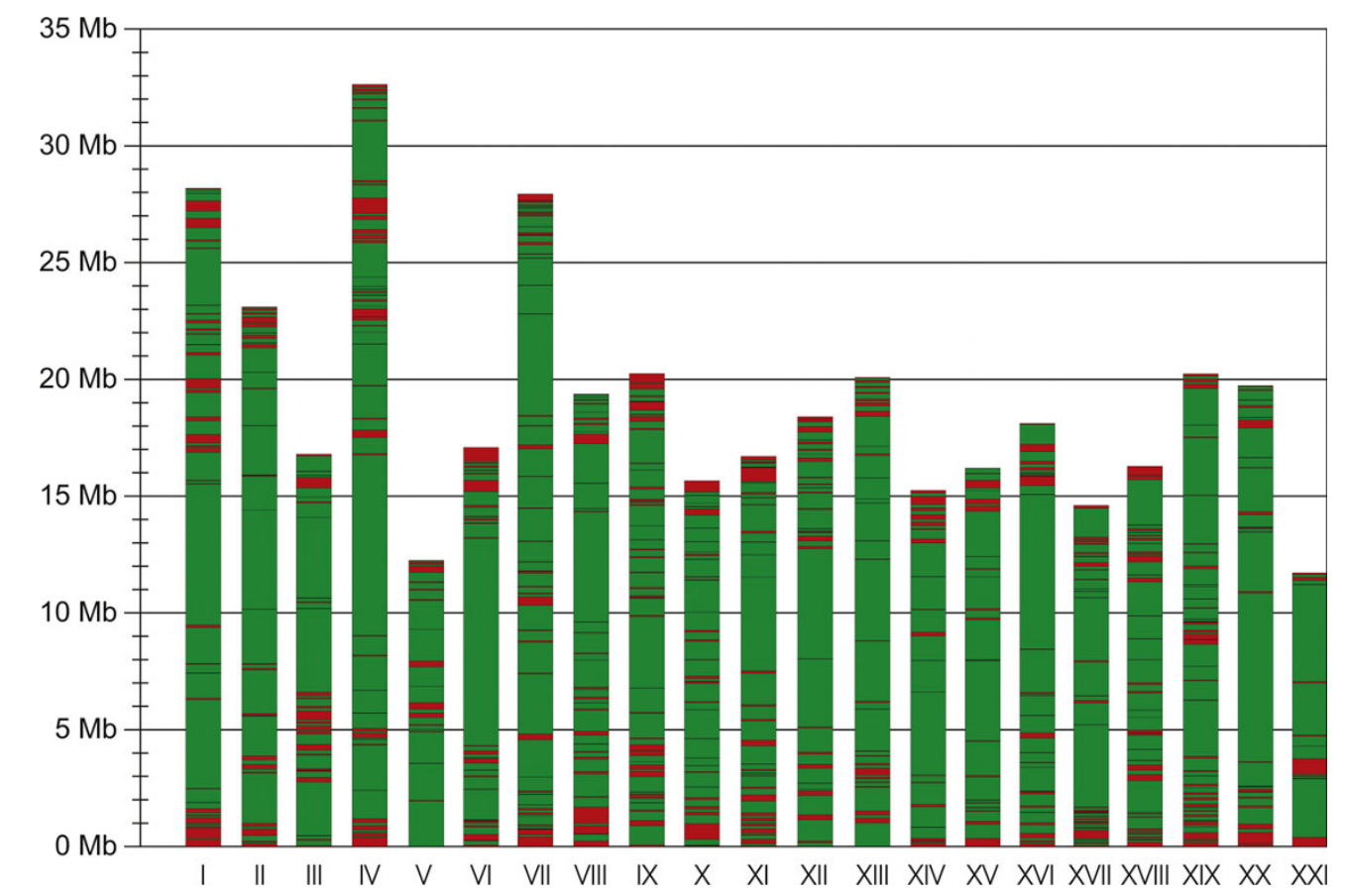

Figure 2 Visualization of comparative sea bass BAC map on 21 stickleback chromosomes. Green regions represent BAC-contigs, which are covered on average 5.25 fold by consistently mapped BAC-clones. In total $87.0 \%$ of the stickleback chromosomes and $85.4 \%$ of annotated genes are covered by the BAC-contigs. Regions with weak mapping results are shown in red and mainly due to repetitive regions like centromeric or telomeric regions, where it is hard to consistently align both BAC-ES. Nevertheless BACs having good matches with one end may be found in these regions. Most of the stickleback chromosomes can be assigned to sea bass genetic linkage groups (see Table 2A, Table 3A and Table 4A).

\section{Conclusions}

The comparative approach enabled a fast and cost effective mapping of large genomic portions of the D. labrax genome; it was further refined by adding WGS data from the early stage sequencing project. Both, WGSand BAC-end sequencing data now represent a solid basis for sequencing the complete genome in a "first map, then sequence" approach with second-generation techniques, such as pyrosequencing. The BAC-map allows splitting the genome into smaller BAC-pools (e.g. covering single chromosomes). This will facilitate the sequence assembly as short reads are a major problem of new sequencing technologies, when sequencing repeat-rich eukaryotic genomes.

The integration of linkage [30], radiation hybrid (Senger, Galibert, in preparation) and BAC-mapping (this study) of sea bass will certainly result in a high quality physical map of the genome. It sets the scene for quantifying polymorphisms and genomic architecture. These are powerful resources for quantitative trait loci mapping, which can be eventually applied in selective breeding using marker assisted selection or introgression [24]. There is also the possibility of genome wide association mapping, based on massive resequencing, to identify genomic regions affecting the phenotype $[49,50]$. Therefore it sets the basic conditions for research to improve the sustainability of sea bass aquaculture in the Mediterranean basin and (shell) fish aquaculture in general.

\section{Methods}

\section{BAC end-sequencing}

The Dicentrarchus labrax BAC-library constructed by Whitaker et al. [26] was obtained from the German resources center for genome research (RZPD, Berlin, Germany). The library comprises pCC1BAC-clones arrayed in $180 \times 384$ well microtiter plates. The total genome coverage of the library is $>12$ fold with an average insert size of $164 \mathrm{kbp}$ per BAC-clone. For end sequencing, BAC-clones were inoculated in $2 \times 384$ deep well plates containing $190 \mu \mathrm{l}$ of $2 \mathrm{YT}$ media and $12.5 \mathrm{mg} / \mathrm{l}$ chloramphenicol and cultivated for $18 \mathrm{~h}$ at $37^{\circ} \mathrm{C}$ with rigorous shaking at $1100 \mathrm{rpm}$ in Titramax 1000 incubators (Heidolph Instruments). BAC-DNA was purified by an automated process that was developed at the MPI for molecular genetics. The process applies size selective precipitation in polyethylene-glycol 6000/2-propanol mixtures and a final washing step with ethanol $70 \%(\mathrm{v} / \mathrm{v})$.

BAC-templates were end sequenced using ABI BigDyeV3.1 Terminator chemistry and T7 or SP6 primers. 

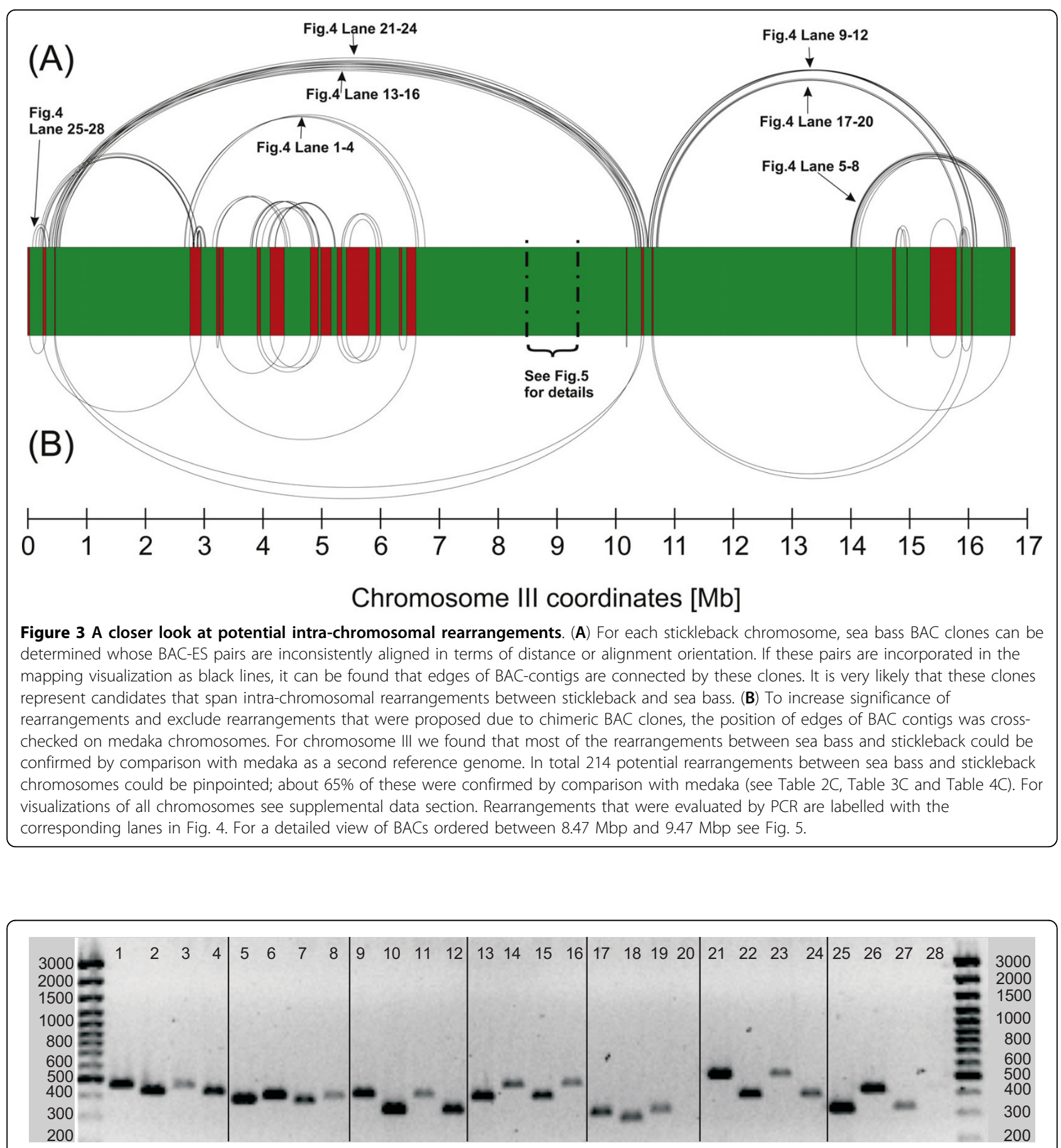

Figure 4 Evaluation of seven potential rearrangements between stickleback chr III and the corresponding sea bass linkage group 10 by means of PCR. Primers were designed on sea bass BAC-ES representing the ends of BAC contigs that seem to be connected by a rearrangement spanning BAC-clone. PCR was performed on the connecting BAC to proof the overlap with both BAC contigs and on genomic DNA to check that the PCR product was a unique marker in the sea bass genome. The amplified markers are shown above, for each rearrangement the first and second lane represents the markers amplified on the rearrangement spanning BAC, the third and fourth lane shows the same markers amplified on genomic sea bass DNA. Lane 1-4: bassbac140-020/stickleback chr III $6.6 \mathrm{Mbp}<>2.66 \mathrm{Mbp}$. Lane 5-8: bassbac137j6/stickleback chr III 14.06 Mbp <> 16.65 Mbp. Lane 9-12: bassbac-1g24/stickleback chr III 16.14 Mbp <> 10.6 Mbp. Lane 13-16: bassbac38h23/stickleback chr III $0.5 \mathrm{Mbp}<>10.55 \mathrm{Mbp}$. Lane 17-20: bassbac-52b18/stickleback chr III $15.89 \mathrm{Mbp}<>10.64$ Mbp. Lane 21-24: bassbac42b12/stickleback chr III $0.457 \mathrm{Mbp}<>10.44 \mathrm{Mbp}$. Lane 25-28: bassbac49h3/stickleback chr III $0.035 \mathrm{Mbp}<>0.311 \mathrm{Mbp}$. Each of the seven BACs had overlaps with the two BAC-contigs predicted by the comparative mapping approach. 12 out of 14 markers were unique in the sea bass genome. 2 markers (Lane 20 and 28) could not be amplified using genomic DNA as a template. 


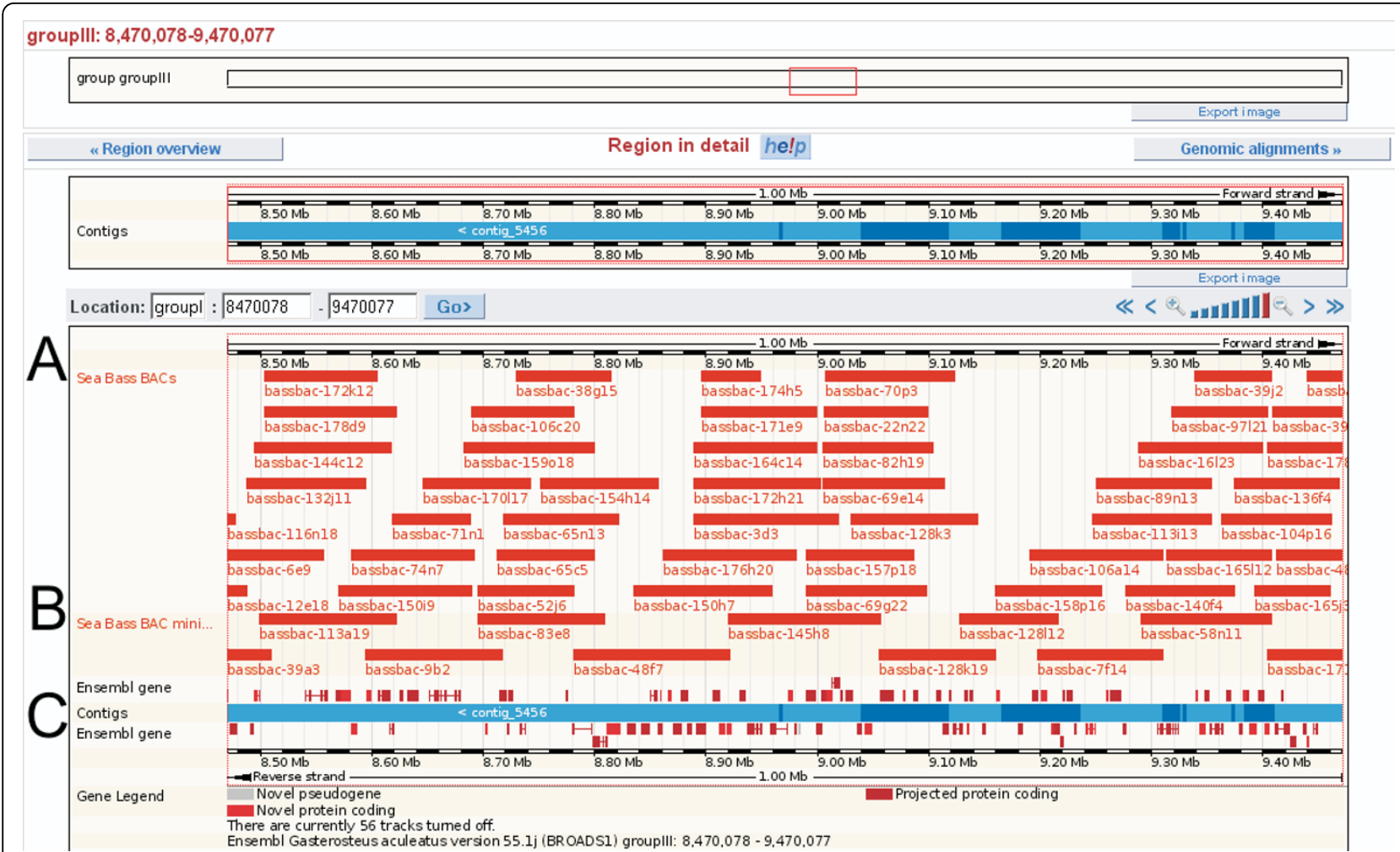

Figure 5 BAC clones in the Ensembl browser. The mapped BAC clones $(\mathbf{A}, \mathbf{B})$ may be browsed alongside the stickleback chromosomes by the Ensembl genome browser (http://www.ensembl.org/Gasterosteus_aculeatus login: kuhl@molgen.mpg.de password: BASSBACMAP2009). This way sea bass BACs can be easily assigned to annotated stickleback genes (C). BACs forming the minimal tiling path are displayed separately (B)

After post-sequencing cleanup by ethanol/NaAcetate precipitation, sequence analysis was performed on ABI3730 $\times 1$ capillary sequencers with either $36 \mathrm{~cm}$ or $50 \mathrm{~cm}$ capillary arrays. Processing of raw sequencing data was done by the PHRED basecaller [51], quality clipping and vector-clipping by LUCY [52].

\section{Whole genome shotgun sequencing}

For the construction of WGS plasmid libraries of Dicentrarchus labrax, we obtained genomic DNA isolated from the same specimen (male 57 originating from the Adriatic clade) that was used for BAC-library construction (kindly provided by A. Libertini, CNR, Venice, Italy through J. B. Taggart, University of Stirling, UK).

Genomic DNA was sheared by ultrasonic sound and size selected for fragment sizes of $0.9-1.5 \mathrm{kbp}$ and $1.5-4 \mathrm{kbp}$. Fragments were polished by T4-DNA-polymerase/DNApolymerase I (Klenow) and ligated with T4-DNA-Ligase into SmaI digested pUC19 sequencing vector. Competent E. coli $\mathrm{DH} 10 \mathrm{~B}$ cells (Invitrogen) were transformed by electroporation, plated on $22 \times 22 \mathrm{~cm}$ agarplates (Nunc) containing LB media with $110 \mathrm{mg} / \mathrm{l}$ Ampicillin, X-GAL and IPTG. After $16 \mathrm{~h}$ of incubation at $37^{\circ} \mathrm{C}$ white colonies were arrayed into 384 well microtiter library plates by a picking robot (Q Bot, Genetix). These plates (media: LB
$+\mathrm{HMFM}+$ Ampicillin) were again incubated for $16 \mathrm{~h}$ at $37^{\circ}$ $\mathrm{C}$ and stored at $-80^{\circ} \mathrm{C}$. Plasmid DNA preparation was done as described for BAC-DNA with the difference that the final washing step with $70 \%(\mathrm{v} / \mathrm{v})$ ethanol was not necessary and a single 384 deepwell microtiter plate filled with $190 \mu \mathrm{l}$ of $2 \mathrm{YT}+110 \mathrm{mg} / \mathrm{l}$ Ampicillin yielded enough template amounts for several sequencing reactions.

Sequencing, sequence analysis and sequence processing of plasmids was done as described above using ABI BigDyeV3.1 Terminator chemistry and M13(-40) or M13(-28) primers.

\section{Alignment of BAC-ES to reference genome}

BAC-ES were aligned by BLAST $[53,54]$ algorithms to genomic sequence of $G$. aculeatus (Assembly: BROAD S1, Feb 2006, http://www.ensembl.org). To minimize computational time BLAST searches were done incrementally beginning with stringent parameters (Megablast, word size 20 , and nucleotide mismatch penalty -1). Results were filtered for alignments that matched with an e-value equal or lower than $10^{-5}$. Additionally, alignments were only submitted to further analysis, if the second best alignment resulted in an e-value that was at least $10^{5}$-fold larger than the e-value of the best alignment. Sequences with alignments not matching 
these criteria were extracted by notseq [55] and subsequently aligned by BLAST searches with lower stringency. Stringency in the following rounds was adjusted by choosing word sizes of 15,11 and 7 .

The number of BAC-ES with alignments meeting our criteria was further improved by adding sequences from whole genome shotgun sequencing of D. labrax. All sequences available were assembled by the Celera Assembler [56]. Contigs that contained BAC-ES were filtered and again aligned to the G. aculeatus genome as described above. Match coordinates of contigs on $G$. aculeatus chromosomes were corrected by position of the BAC-ES in the contigs and assigned to the corresponding BAC-ES.

\section{Calculating and visualizing the comparative map}

Resulting BLAST-tables of both approaches were screened for BACs that were aligned with both ends. These BACs were further screened for matches to the same chromosome in G. aculeatus and then checked for consistent orientation and distance.

BACs that matched all consistency criteria were chosen for the calculation of a minimal tiling path. Starting with a first BAC-clone, BAC-contigs were constructed by choosing BACs that were overlapping and maximizing the contig in length. These analyses were done by common spreadsheet software and scripting language. BAC-contigs arranged on the 21 G. aculeatus chromosomes were visualized by passing coordinates to a vector graphics application (CorelDRAW version 11, Corel corp., Ottawa, Canada). To view the BAC map alongside the annotated stickleback genome the mapping coordinates were uploaded to the ensembl genome browser as a GFF formatted textfile.

\section{Dealing with possible rearrangements and checking them on a second reference genome}

The subset of BAC-ES that aligned to the same chromosome but did not match consistency criteria could be due to intra-chromosomal rearrangements between stickleback and sea bass. These clones were visualized as black arcs on the stickleback chromosomes. If these arcs were starting not at the edge of contigs they were manually removed. To check if the rearrangement spanning BAC-ES have a consistent order in the medaka genome, we exploited stickleback and medaka synteny of orthologous genes. Using the biomart tool a table was prepared that showed the genes annotated to stickleback with their orthologous position in medaka. Furthermore the coordinates of contig starts and ends from the sea bass BAC-map were implemented in the table. In this way the position of sea bass contig starts and ends on medaka could be mapped to stickleback chromosome coordinates. BAC-contig edges that are located next to each other in medaka were subsequently visualized by arcs, in many cases confirming a connection between contigs that was also found before by non-consistent matching sea bass BAC-ES.

\section{Evaluation of several rearrangements by means of PCR}

Seven potential rearrangements between stickleback chr III and the corresponding sea bass linkage group were checked by means of PCR. Primers for PCR were designed on BAC-ES representing the end of BAC-contigs that seem to be connected by a rearrangement spanning clone. Subsequently amplification of the chosen markers was carried out using the rearrangements spanning clones as templates. If both BAC-contig end markers can be amplified on a rearrangement spanning $\mathrm{BAC}$, the overlap and therefore connection of the two BAC-contigs in sea bass is confirmed. Additionally markers were amplified on genomic DNA of sea bass to check that they are unique markers in the genome. The PCR was set up as $50 \mu \mathrm{l}$ reactions. For amplification of BAC-templates we added $2 \mu \mathrm{l}$ of overnight culture to the PCR, while amplification of genomic DNA was carried out by adding $2 \mu \mathrm{l}$ DNA with a concentration of 45 $\mathrm{ng} / \mu \mathrm{l}$ to the PCR. Composition of PCR was as follows: $0.3 \mu \mathrm{M}$ for each primer, $300 \mu \mathrm{M}$ dNTPs, $75 \mathrm{mM}$ TRIS$\mathrm{HCl}, \mathrm{pH}$ 9, $20 \mathrm{mM}\left(\mathrm{NH}_{4}\right)_{2} \mathrm{SO}_{4}, 0.01 \%$ Tween 20, 2.5 $\mathrm{mM} \mathrm{MgCl} 2,0.1 \mathrm{U} / \mu \mathrm{l}$ Taq-DNA-polymerase and $0.5 \mathrm{M}$ Betaine. Thermocycler profile was: Step I: $5 \mathrm{~min}$ at $94^{\circ}$ C. Step II: $30 \mathrm{~s}$ at $94^{\circ} \mathrm{C}$. Step III: $30 \mathrm{~s}$ at $55^{\circ} \mathrm{C}$. Step IV: 1 min at $72^{\circ} \mathrm{C}$. Step V: $7 \mathrm{~min}$ at $72^{\circ} \mathrm{C}$. Step VI: hold at $4^{\circ}$ C. Steps II-IV were repeated 25 times. PCR products were analyzed on $1.5 \%$ agarose gels and stained with ethidium bromide.

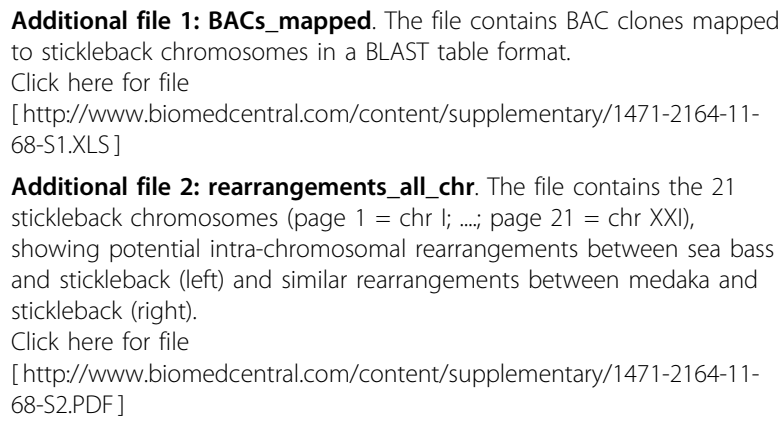

\section{Acknowledgements}

The authors acknowledge J.B. Taggart for providing sea bass genomic DNA We also thank B. Baumann, B. Köysüren, J. Thiel, A. Kühn and the members of Richard Reinhardt's group for technical assistance. Research was supported by the Max-Planck-Society, the European Commission of the European Union through the Network of Excellence Marine Genomics Europe (contract GOCE-CT-2004-505403) and the FP6 project Aquafirst (EU contract number STREP-2004-513692). 


\section{Author details}

'Max Planck Institute for Molecular Genetics, Ihnestr. 63, D-14195 Berlin, Germany. ${ }^{2}$ Centre of Marine Sciences (CCMAR), University of Algarve, Gambelas, 8005-139 Faro, Portugal. ${ }^{3}$ Laboratory of Animal Diversity and Systematics, Katholieke Universiteit Leuven, Ch. Deberiotstraat 32, B-3000 Leuven, Belgium.

\section{Authors' contributions}

HK established protocols for automated BAC, plasmid purification and subsequent Sanger sequencing, assembled the derived sequencing data, built the comparative map of BAC clones and wrote the manuscript. $A B$ provided tools for bioinformatic analyses. GW programmed robotics for the automation of the purification process. AVMC and FAMV helped writing the manuscript. RR provided robotics, sequencing technologies and corrected the manuscript. All authors read and approved the manuscript.

\section{Received: 28 September 2009}

Accepted: 27 January 2010 Published: 27 January 2010

\section{References}

1. Barrett RD, Rogers SM, Schluter D: Natural selection on a major armor gene in threespine stickleback. Science 2008, 322(5899):255-257.

2. Fujimura K, Okada N: Shaping of the lower jaw bone during growth of Nile tilapia Oreochromis niloticus and a Lake Victoria cichlid Haplochromis chilotes: a geometric morphometric approach. Dev Growth Differ 2008, 50(8):653-663.

3. Amatruda JF, Patton EE: Genetic models of cancer in zebrafish. Int Rev Cell Mol Biol 2008, 271:1-34.

4. Aparicio S, Morrison A, Gould A, Gilthorpe J, Chaudhuri C, Rigby P, Krumlauf $R$, Brenner $S$ : Detecting conserved regulatory elements with the model genome of the Japanese puffer fish, Fugu rubripes. Proc Natl Acad Sci USA 1995, 92(5):1684-1688.

5. Kingsley DM, Peichel CL, Ostlund-Nilsson S, Mayer I: The molecular genetics of evolutionary change in sticklebacks. Biology of the three-spine stickleback Huntingford FA: CRC Press 2007, 41(81).

6. Krumschnabel G, Podrabsky JE: Fish as model systems for the study of vertebrate apoptosis. Apoptosis 2009, 14(1):1-21.

7. Jaillon O, Aury JM, Brunet F, Petit JL, Stange-Thomann N, Mauceli E, Bouneau L, Fischer C, Ozouf-Costaz C, Bernot A, Nicaud S, Jaffe D, Fisher S, Lutfalla G, Dossat C, Segurens B, Dasilva C, Salanoubat M, Levy M, Boudet N, Castellano S, Anthouard V, Jubin C, Castelli V, Katinka M, Vacherie B, Biemont C, Skalli Z, Cattolico L, Poulain J, et al: Genome duplication in the teleost fish Tetraodon nigroviridis reveals the early vertebrate protokaryotype. Nature 2004, 431(7011):946-957.

8. Aparicio S, Chapman J, Stupka E, Putnam N, Chia JM, Dehal P, Christoffels A, Rash S, Hoon S, Smit A, Gelpke MD, Roach J, Oh T, Ho IY, Wong M, Detter C, Verhoef F, Predki P, Tay A, Lucas S, Richardson P, Smith SF, Clark MS, Edwards YJ, Doggett N, Zharkikh A, Tavtigian SV, Pruss D, Barnstead M, Evans C, et al: Whole-genome shotgun assembly and analysis of the genome of Fugu rubripes. Science 2002, 297:1301-1310.

9. Kasahara M, Naruse K, Sasaki S, Nakatani Y, Qu W, Ahsan B, Yamada T, Nagayasu Y, Doi K, Kasai Y, Jindo T, Kobayashi D, Shimada A, Toyoda A, Kuroki Y, Fujiyama A, Sasaki T, Shimizu A, Asakawa S, Shimizu N, Hashimoto S, Yang J, Lee Y, Matsushima K, Sugano S, Sakaizumi M, Narita T, Ohishi K, Haga S, Ohta F, et al: The medaka draft genome and insights into vertebrate genome evolution. Nature 2007, 447:714-719.

10. Jekosch $\mathrm{K}$ : The zebrafish genome project: sequence analysis and annotation. Methods Cell Biology 2004, 77:225-239.

11. Chen E, Ekker SC: Zebrafish as a genomics research model. Curr Pharm Biotechnol 2004, 5(5):409-413.

12. Takeda H: Draft genome of the medaka fish: a comprehensive resource for medaka developmental genetics and vertebrate evolutionary biology. Dev Growth Differ 2008, 50(Suppl 1):S157-166.

13. Hunt G, Bell MA, Travis MP: Evolution toward a new adaptive optimum: phenotypic evolution in a fossil stickleback lineage. Evolution 2008, 62(3):700-710.

14. Roest Crollius H, Weissenbach J: Fish genomics and biology. Genome Res 2005, 15(12):1675-1682.

15. Dahm $R$, Geisler R: Learning from small fry: the zebrafish as a genetic model organism for aquaculture fish species. Mar Biotechnol (NY) 2006, 8(4):329-345.
16. Sarropoulou E, Nousdili D, Magoulas A, Kotoulas G: Linking the genomes of nonmodel teleosts through comparative genomics. Marine Biotechnology 2008, 10:227-233.

17. Schilling TF, Webb J: Considering the zebrafish in a comparative context. J Exp Zoolog B Mol Dev Evol 2007, 308(5):515-522.

18. FAO: The state of the world fisheries and aquaculture. Rome: Food and Agriculture Organization of the United Nations 2006

19. Naylor RL, Burke M: Aquaculture and ocean resources: Raising tigers of the sea. Annu Rev Environ Resour 2005, 30:185-210.

20. Tacon AGJ, Metian M: Fishing for Aquaculture: Non-Food Use of Small Pelagic Forage Fish-A Global Perspective. Reviews in Fisheries Science 2009, 17(3):305-317.

21. Naylor RL, Goldburg RJ, Primavera JH, Kautsky N, Beveridge MC, Clay J, Folke C, Lubchenco J, Mooney H, Troell M: Effect of aquaculture on world fish supplies. Nature 2000, 405(6790):1017-1024.

22. Leaver MJ, Villeneuve LA, Obach A, Jensen L, Bron JE, Tocher DR, Taggart JB: Functional genomics reveals increases in cholesterol biosynthetic genes and highly unsaturated fatty acid biosynthesis after dietary substitution of fish oil with vegetable oils in Atlantic salmon (Salmo salar). BMC Genomics 2008, 9(299)

23. Vandeputte M, Baroiller JF, Haffray P, Quillet E: Genetic improvement of fish: Achievements and challenges for tomorrow. Cahiers Agricultures 2009, 18(2):262-269.

24. Canario AVM, Bargelloni L, Volckaert F, Houston RD, Massault C, Guiguen Y: Genomics Toolbox for Farmed Fish. Reviews in Fisheries Science 2008, 16:3-15.

25. Volckaert FAM, Batargias C, Canario AVM, Chatziplis D, Chistiakov DA, Haley CS, Libertini A, Tsigenopoulos C, Kocher TD, Kole C: European Sea Bass. Genome mapping and Genomics in Fishes and Aquatic Animals Berlin Heidelberg: Springer-Verlag 2008, 2:117-130.

26. Whitaker HA, MCAndrew BJ, Taggart JB: Construction and characterization of a BAC-library for the European sea bass Dicentrarchus labrax. Animal Genetics 2006, 37(526)

27. Chistiakov DA, Hellemans B, Tsigenopoulos CS, Law AS, Bartley N, Bertotto D, Libertini A, Kotoulas G, Haley CS, Volckaert FA: Development and linkage relationships for new microsatellite markers of the sea bass (Dicentrarchus labrax L.). Anim Genet 2004, 35.

28. Souche E: Genomic variation in European sea bass: from SNP discovery within ESTs to genome scan. Leuven: Katholieke Universiteit Leuven, Belgium 2009.

29. Chistiakov DA, Hellemans B, Haley CS, Law AS, Tsigenopoulos CS, Kotoulas G, Bertotto D, Libertini A, Volckaert FA: A microsatellite linkage map of the European Seabass Dicentrarchus labrax L. Genetics 2005, 170:1821-1826.

30. Chistiakov DA, Tsigenopoulos CS, Lagnel J, Yuanmei G, Hellemans B, Haley CS, Volckaert FAM, Kotoulas G: A combined AFLP and microsatellite linkage map and pilot comparative genomic analysis of European sea bass Dicentrarchus labrax L. Animal Genetics 2008, 39:623-634.

31. Peruzzi $S$, Chatain B, Menu B: Flow cytometric determination of genome size in European seabass (Dicentrarchus labrax), gilthead seabream (Sparus aurata), thinlip mullet (Liza ramada), and European eel (Anguilla anguilla). Aquat Living Resour 2005, 18:77-81.

32. Elgar G, Sandford R, Aparicio S, Macrae A, Venkatesh B, Brenner S: Small is beautiful: comparative genomics with the pufferfish (Fugu rubripes). Trends Genet 1996, 12:145-150.

33. Lander ES, Linton LM, Birren B, Nusbaum C, Zody MC, Baldwin J, Devon K, Dewar K, Doyle M, FitzHugh W, Funke R, Gage D, Harris K, Heaford A, Howland J, Kann L, Lehoczky J, LeVine R, McEwan P, McKernan K, Meldrim J, Mesirov JP, Miranda C, Morris W, Naylor J, Raymond C, Rosetti M, Santos R, Sheridan A, Sougnez C, et al: Initial sequencing and analysis of the human genome. Nature 2001, 409(6822):860-921.

34. Venter JC, Adams MD, Myers EW, Li PW, Mural RJ, Sutton GG, Smith HO, Yandell M, Evans CA, Holt RA, Gocayne JD, Amanatides P, Ballew RM, Huson DH, Wortman JR, Zhang Q, Kodira CD, Zheng XH, Chen L, Skupski M, Subramanian G, Thomas PD, Zhang J, Gabor Miklos GL, Nelson C, Broder S, Clark AG, Nadeau J, McKusick VA, Zinder N, et al: The sequence of the human genome. Science 2001, 291(5507):1304-1351.

35. Wang J, Wang W, Li R, Li Y, Tian G, Goodman L, Fan W, Zhang J, Li J, Zhang JGY, Feng B, Li H, Lu Y, Fang X, Liang H, Du Z, Li D, Zhao Y, Hu Y, Yang Z, Zheng H, Hellmann I, Inouye M, Pool J, Yi X, Zhao J, Duan J, Zhou Y, Qin J, Ma L, Li G, Yang Z, Zhang G, Yang B, Yu C, Liang F, Li W, 
Li S, Li D, Ni P, Ruan J, Li Q, Zhu H, Liu D, Lu Z, Li N, Guo G, Zhang J, Ye J, Fang L, Hao Q, Chen Q, Liang Y, Su Y, San A, Ping C, Yang S, Chen F, Li L, Zhou K, Zheng H, Ren Y, Yang L, Gao Y, Yang G, Li Z, Feng X, Kristiansen K, Wong GK, Nielsen R, Durbin R, Bolund L, Zhang X, Li S, Yang H, Wang J: The diploid genome sequence of an Asian individual. Nature 2008, 456:49-51.

36. Margulies M, Egholm M, Altman WE, Attiya S, Bader JS, Bemben LA, Berka J, Braverman MS, Chen YJ, Chen Z, Dewell SB, Du L, Fierro JM, Gomes XV, Godwin BC, He W, Helgesen S, Ho CH, Irzyk GP, Jando SC, Alenquer MLJTP, Jirage KB, Kim JB, Knight JR, Lanza JR, Leamon JH, Lefkowitz SM, Lei M, Li J, Lohman $\mathrm{KL}$, et al: Genome sequencing in microfabricated high-density picolitre reactors. Nature 2005, 437:376-380.

37. Quinn NL, Levenkova N, Chow W, Bouffard P, Boroevich KA, Knight JR, Jarvie TP, Lubieniecki KP, Desany BA, Koop BF, Harkins TT, Davidson WS: Assessing the feasibility of GS FLX Pyrosequencing for sequencing the Atlantic salmon genome. BMC Genomics 2008, 9(404).

38. Goldberg SM, Johnson J, Busam D, Feldblyum T, Ferriera S, Friedman R, Halpern A, Khouri H, Kravitz SA, Lauro FM, Li K, Rogers YH, Strausberg R, Sutton G, Tallon L, Thomas T, Venter E, Frazier M, Venter JC: A Sanger/ pyrosequencing hybrid approach for the generation of high-quality draft assemblies of marine microbial genomes. Proc Natl Acad Sci USA 2006, 103:11240-11245.

39. Nelson JS: Fishes of the world New York: Wiley, 42006.

40. Shizuya H, Birren B, Kim UJ, Mancino V, Slepak T, Tachiiri YMS: Cloning and stable maintenance of 300-kilobase-pair fragments of human DNA in Escherichia coli using an F-factor-based vector. Proc Natl Acad Sci USA 1992, 89:8794-8797.

41. Khorasani MZ, Hennig S, Imre G, Asakawa S, Palczewski S, Berger A, Hori H, Naruse K, Mitani H, Shima A, Lehrach H, Wittbrodt J, Kondoh H, Shimizu N, Himmelbauer $\mathrm{H}$ : A first generation physical map of the medaka genome in BACs essential for positional cloning and clone-by-clone based genomic sequencing. Mech Dev 2004, 121:903-913.

42. Luo M-C, Thomas C, You FM, Hsiao J, Ouyang S, Buell CR, Malandro M, McGuire PE, Anderson OD, Dvorak J: High-throughput fingerprinting of bacterial artificial chromosomes using the SNaP-shot labeling kit and sizing of restriction fragments by capillary electrophoresis. Genomics 2003, 82:378-389.

43. Cheung VG, Dalrymple HL, Narasimhan S, Watts J, Schuler G, Raap AK Morley M, Bruzel A: A resource of mapped human bacterial artificial chromosome clones. Genome Research 1999, 9:989-993.

44. Fujiyama A, Watanabe H, Toyoda A, Taylor TD, Itoh T, Tsai SF, Park HS, Yaspo ML, Lehrach H, Chen Z, Fu G, Saitou N, Osoegawa K, de Jong PJ, Suto Y, Hattori M, Sakaki Y: Construction and analysis of a humanchimpanzee comparative clone map. Science 2002, 295:131-134.

45. Larkin DM, Wind Everts-van der A, Rebeiz M, Schweitzer PA, Bachman S, Green C, Wright CL, Campos EJ, Benson LD, Edwards J, Liu L, Osoegawa K, Womack JE, de Jong PJ, Lewin HA: A cattle-human comparative map built with cattle BAC-ends and human genome sequence. Genome Research 2003, 13:1966-1972.

46. Miya M, Satoh TP, Nishida : The phylogenetic position of toadfishes (Order Batrachoidiformes) in the higher ray-finned fishes as inferred from partitioned Bayesian analysis of 102 whole mitochondrial sequences. Biol Jour Linn Soc 2005, 85:289-306.

47. Imai S, Sasaki T, Shimizu A, Asakawa S, Hori H, Shimizu N: The genome size evolution of medaka (Oryzias latipes) and fugu (Takifugu rubripes). Genes Genet Syst 2007, 82(2):135-144.

48. Ferraresso S, Kuhl H, Milan M, Ritchie DW, Secombes CJ, Reinhardt R, Bargelloni L: Identification and characterisation of a novel immune-type receptor (NITR) gene cluster in the European sea bass, Dicentrarchus labrax, reveals recurrent gene expansion and diversification by positive selection. Immunogenetics 2009, 61:773-788.

49. Barendse W, Harrison BE, Bunch RJ, Thomas MB: Variation at the Calpain 3 gene is associated with meat tenderness in zebu and composite breeds of cattle. BMC Genet 2008, 9(41).

50. Nordborg M, Weigel D: Next-generation genetics in plants. Nature 2008 456(7223):720-723

51. Ewing B, Green P: Base-calling of automated sequencer traces using phred. II. Error probabilities. Genome Research 1998, 8:186-194.

52. Chou HH, Holmes MH: DNA sequence quality trimming and vector removal. Bioinformatics 2001, 17:1093-1104.
53. Altschul SF, Gish W, Miller W, Myers EW, Lipman DJ: Basic local alignment search tool. Journal of Molecular Biology 1990, 215:403-410.

54. Altschul SF, Madden TL, Schäffer AA, Zhang J, Zhang Z, Miller W, Lipman DJ: Gapped BLAST and PSI-BLAST: a new generation of protein database search programs. Nucleic Acids Research 1997, 25:3389-3402.

55. Rice P, Longden I, Bleasby A: EMBOSS: The European Molecular Biology Open Software Suite. Trends in Genetics 2000, 16:276-277.

56. Miller JR, Delcher AL, Koren S, Venter E, Walenz BP, Brownley A, Johnson J, Li K, Mobarry C, Sutton G: Aggressive assembly of pyrosequencing reads with mates. Bioinformatics 2008, 24:2818-2824.

doi:10.1186/1471-2164-11-68

Cite this article as: Kuhl et al:: The European sea bass Dicentrarchus labrax genome puzzle: comparative BAC-mapping and low coverage shotgun sequencing. BMC Genomics 2010 11:68.

\section{Submit your next manuscript to BioMed Central and take full advantage of:}

- Convenient online submission

- Thorough peer review

- No space constraints or color figure charges

- Immediate publication on acceptance

- Inclusion in PubMed, CAS, Scopus and Google Scholar

- Research which is freely available for redistribution

Submit your manuscript at www.biomedcentral.com/submit
Biomed Central 